\title{
Cytotoxic Potential and Molecular Pathway Analysis of Silver Nanoparticles in Human Colon Cancer Cells HCT116
}

\author{
Sangiliyandi Gurunathan, Muhammad Qasim, Chanhyeok Park, Hyunjin Yoo, Jin-Hoi Kim \\ and Kwonho Hong *
}

Department of Stem Cell and Regenerative Biotechnology and Humanized Pig Center (SRC), Konkuk Institute of Technology, Konkuk University, Seoul 05029, Korea; gsangiliyandi@yahoo.com (S.G.); qasimattock@gmail.com (M.Q.); chanhyeok.park3751@gmail.com (C.P.); hyunjinyoo7@gmail.com (H.Y.); jhkim541@konkuk.ac.kr (J.-H.K.)

* Correspondence: hongk@konkuk.ac.kr; Tel.: +82-2-450-0560; Fax: +82-2-444-3490

Received: 18 July 2018; Accepted: 30 July 2018; Published: 2 August 2018

\begin{abstract}
Silver nanoparticles (AgNPs) have gained attention for use in cancer therapy. In this study, AgNPs were biosynthesized using naringenin. We investigated the anti-colon cancer activities of biogenic AgNPs through transcriptome analysis using RNA sequencing, and the mechanisms of AgNPs in regulating colon cancer cell growth. The synthesized AgNPs were characterized using UV-visible spectroscopy (UV-vis), X-ray diffraction (XRD), Fourier-transform infrared spectroscopy (FTIR), dynamic light scattering (DLS), and transmission electron microscopy (TEM). The AgNPs were spherical with sizes of 2-10 nm. Cytotoxicity assays indicated that the AgNPs in HCT116 colorectal cancer cells were very effective at low concentrations. The viability and proliferation of colon cancer cells treated with $5 \mu \mathrm{g} / \mathrm{mL}$ biogenic AgNPs were reduced by $50 \%$. Increased lactate dehydrogenase leakage (LDH), reactive oxygen species (ROS) generation, malondialdehyde (MDA), and decreased dead-cell protease activity and ATP generation were observed. This impaired mitochondrial function and DNA damage led to cell death. The AgNPs upregulated and downregulated the most highly ranked biological processes of oxidation-reduction and cell-cycle regulation, respectively. Kyoto Encyclopedia of Genes and Genomes (KEGG) analysis showed that AgNPs upregulated GADD45G in the p53 pathway. Thus, the AgNP tumor suppressive effects were mediated by cell apoptosis following DNA damage, as well as by mitochondrial dysfunction and cell-cycle arrest following aberrant regulation of p53 effector proteins. It is of interest to mention that, to the best of our knowledge, this study is the first report demonstrating cellular responses and molecular pathways analysis of AgNPs in HCT116 colorectal cancer cells.
\end{abstract}

Keywords: silver nanoparticles; cell viability; oxidative stress; mitochondria; DNA damage; KEGG analysis; biological pathways

\section{Introduction}

According to the International Agency for Research on Cancer, colorectal cancer (CRC) is the third most commonly diagnosed malignancy in men and the second most commonly occurring cancer in women [1]. CRC is the third most common cancer and the fourth leading cause of cancer-related deaths worldwide, with nearly 1.4 million new cases diagnosed in 2012. It was predicted that the 2.4 million cases of CRC will increase to 1.36 million for men and 1.08 million for women by 2035 [2]. Thus, it is necessary to reduce the burden of CRC $[1,3]$. Treatment of CRC remains a major challenge for researchers, gastroenterologists, and oncologists. The compound, 5-fluorouracil, is the only approved drug for treating advanced CRC [4]. Although chemotherapy remains the standard treatment, it causes 
several side effects such as nausea, vomiting, loss of appetite, constipation or diarrhea, and alopecia. Therefore, alternative therapeutic strategies are needed [5].

Recently, silver nanoparticles (AgNPs) showed potential for therapeutic applications because of their unique properties, and they were used as strong broad-spectrum antimicrobial agents in textiles, food storage containers, antiseptic sprays, catheters, bandages, and anti-cancer agents [6,7]. AgNPs are promising anti-cancer agents. A low concentration of AgNPs causes DNA damage and chromosomal aberrations without significant toxicity $[8,9]$. Lima et al. observed no genotoxicity effects for different human culture cells treated with up to $10 \mathrm{mg} / \mathrm{mL}$ of capped AgNPs with average sizes of $6-80 \mathrm{~nm}$. AgNPs are known to interact with cells and regulate various cellular responses in both passive and active manners [10]. Gurunathan et al. demonstrated the anti-angiogenic properties of AgNPs in vascular endothelial cells, which showed equivalent potency to a natural anti-angiogenic molecule, known as pigment epithelium-derived factor, by inhibiting the phosphorylation of protein kinase B/Akt [11]. SriRam et al. demonstrated the potential cytotoxicity against Dalton's lymphoma ascites (DLA) and DLA-induced tumors in mice, with significantly increased survival times in the tumor mouse model compared to the untreated group [12]. Low concentrations of poly ( $N$-vinyl-2-pyrrolidone)-coated AgNPs inhibited the viability of acute myeloid leukemia cells and the viability of K562 cells in a dose-dependent manner after entering the cells via endocytic pathway endosomes [13]. Importantly, AgNPs were shown to exert anti-cancer effects and exhibited cytotoxicity via different mechanisms on cancer cells, such as by inducing cellular apoptosis through mitochondria-dependent and mitochondria-independent pathways against various types of cancer cells, including human breast cancer cells (MCF-7, MDA-MB-231), lung cancer cells (A549), liver (HepG2), and skin and oral carcinoma cell lines (HT144), via the leakage of lactate dehydrogenase, reactive oxygen species (ROS) generation, and the impairment of mitochondrial dysfunction [14-19]. However, the anti-cancer activity of AgNPs depends on various factors such as their size, shape, and surface coatings, as well as the surface charge, the type of cells, and the type of reducing agents used to synthesize the AgNPs. Although conventional physical and chemical methods are simple, the processes are energy-intensive and require toxic chemicals [15]. Additionally, synthetic capping agents such as polyethylene glycol, polyvinyl pyrrolidone, and polyvinyl alcohol are toxic and non-biodegradable. Therefore, the interest in using biomolecules as capping agents for AgNPs increased [20].

The transcriptomics field advanced rapidly in recent years with the introduction of next-generation sequencing technologies, such as RNA sequencing (RNA-Seq), which may displace complementary DNA (cDNA) microarrays as the favored method for gene-expression profiling of cells and tissues $[21,22]$. Transcriptome analysis associated with bioinformatics data-mining tools can be used to simultaneously analyze numerous genes/targets and to identify the mechanisms of action after treatments. RNA-Seq serves as a useful tool for identifying differentially expressed genes following treatment with various compounds [23]. RNA-Seq has several advantages compared to whole-genome sequencing; it is mainly focused on transcribed regions of genomes, it is free from probe-specific hybridization of microarrays, and it has expansive coverage, allowing for unbiased detection of both coding and noncoding novel transcripts, as well as low-abundance transcripts [23-25].

To overcome the limitations of conventional methods, the development of AgNPs with well-controlled morphological and physicochemical features for physiological application in humans is necessary; therefore, we adopted a biological method for synthesizing AgNPs using a pure aqueous solution of naringenin (NAR). Few studies examined the synthesis of AgNPs through pure flavonoid reduction of silver. In this study, we systematically analyzed the anti-cancer potential of the NAR stabilized AgNPs using HCT116 human colon cancer cell lines, and the mechanism of action of AgNPs in regulating the growth of CRC cells using the RNA-Seq approach. Although AgNPs were shown to inhibit cell viability and proliferation in different types of cancer cells, the mechanism is unknown. Therefore, profiling of gene expression can also be used as a new tool for evaluating interactions between nanoparticles and biological systems to reveal molecular mechanisms. Moreover, our method is useful for predicting mechanisms of toxicity of AgNPs in cancer cells. 


\section{Results and Discussion}

\subsection{Synthesis and Characterization of AgNPs Using NAR}

The synthesis of AgNPs was carried out using a pure aqueous solution of NAR ( $50 \mu \mathrm{M})$ mixed with $2 \mathrm{mM}$ silver nitrate at $37^{\circ} \mathrm{C}$ for $1 \mathrm{~h}$. NAR is a flavonoid with significant antibiotic, anti-cancerous, and anti-inflammatory properties against various types of cancer cells [26-28]. Color formation rapidly occurred in this mixture, possibly because of the reaction between Ag ions and NAR [12,28]. The synthesis of AgNPs was confirmed using UV-visible spectroscopy (UV-vis). The UV-visible spectrum showed a single absorption peak at $440 \mathrm{~nm}$, suggesting that the synthesized AgNPs were pure (Figure 1A). In aqueous solution, AgNPs exhibit strong surface plasmon resonance, and their absorbance spectra depend on their size, shape, and morphology. The synthesis of AgNPs using pure flavonoids is faster than using the whole plant extract, and prevents the inclusion of impurities [28-30].

To determine the crystalline nature and surface morphology of the synthesized AgNPs, X-ray diffraction (XRD) analysis was performed between the $2 \theta$ range of $20^{\circ}$ and $80^{\circ}$. Figure $1 \mathrm{~B}$ shows the XRD pattern of AgNPs synthesized by reacting aqueous silver salt with NAR. The XRD pattern showed characteristic peaks of AgNPs, confirming the crystalline nature of the AgNPs. High-intensity peaks of AgNPs synthesized using NAR were observed at approximately $38^{\circ}, 44^{\circ}$, and $76^{\circ}$, corresponding to (111), (200), and (311) Bragg reflections, respectively, and are the precise peak positions for the face-centered cubic lattice structure of silver. The average particle size obtained based on the XRD pattern using the Scherrer equation was approximately $6 \mathrm{~nm}$ for AgNPs synthesized using NAR. Our findings agree with those of previous reports of AgNPs synthesis using plant extracts [14], using various flavonoids such as hesperidin, NAR, and diosmin [28], and using leaf extracts of Ocimum Sanctum and its derivative, quercetin [30].

To determine whether NAR was responsible for reducing silver ions to AgNPs, we performed Fourier-transform infrared (FTIR) spectroscopy analysis. As shown in Figure 1C, the synthesized AgNPs showed peaks at approximately 1640, 2110, and $3270 \mathrm{~cm}^{-1}$, which correspond to the groups $\mathrm{C}=\mathrm{C}, \mathrm{C} \equiv \mathrm{C}$, and amine $\mathrm{N}-\mathrm{H} / \mathrm{O}-\mathrm{H}$ stretching vibrations, respectively. This indicates that NAR was responsible for reducing silver ions to AgNPs, which strongly corresponds to the same functional groups present in quercetin responsible for reducing silver into AgNPs [30,31]. Furthermore, IR spectra depicted a strong stretching of the $\mathrm{O}-\mathrm{H}$ bond as a strong signal peak between 3000 and $3500 \mathrm{~cm}^{-1}[14,15,17]$. A previous study detected a strong signal for an $\mathrm{O}-\mathrm{H}$ bond in flavonoids used as reducing agents to synthesize AgNPs [32].

Although the size and morphology of the particles can be measured using transmission electron microscopy (TEM), it is important to determine the particle size in solution before examining toxicity in cells. Dynamic light scattering (DLS) methods are used to measure large numbers of particles in a single solution $[15,17]$. The particle size distribution determined using DLS for the AgNP mixture is shown in Figure 1D. The particle-size histogram indicated that AgNPs varied in size from 1 to $10 \mathrm{~nm}$ with a mean diameter of $6 \mathrm{~nm}$. DLS intensity analysis revealed one broad and sharp peak with an average size of $6 \pm 1 \mathrm{~nm}$. To determine the uniformity of particle sizes and morphologies, we performed TEM. The TEM image in Figure 1E shows the spherical shape and homogeneous particle size distribution of AgNPs in the micrograph, with sizes close to those determined using DLS. Figure 1F summarizes the size measurement results of AgNPs from the TEM images. Collectively, both TEM and DLS analyses showed that the synthesized AgNPs were $6 \mathrm{~nm}$. Sahu et al. reported that the sizes of nanoparticles synthesized from hesperidin, diosmin, and NAR were approximately $5-50 \mathrm{~nm}$, 5-40 nm, and 20-80 nm, respectively [28]. Hesperidin- and NAR-derived AgNPs were oval-shaped and polydispersed, while diosmin-derived AgNPs were hexagonal-shaped. Prathna et al. produced AgNPs with an average size of $50 \mathrm{~nm}$ using citrus plant extract [33]. Jain and Mehata reported that Tulsi extract- and quercetin-mediated synthesis of AgNPs had average sizes of 14.6 and $11.35 \mathrm{~nm}$, respectively [30]. Our findings suggest that NAR produced even smaller particles, which can easily penetrate cells and release silver ions faster compared to larger particles. 

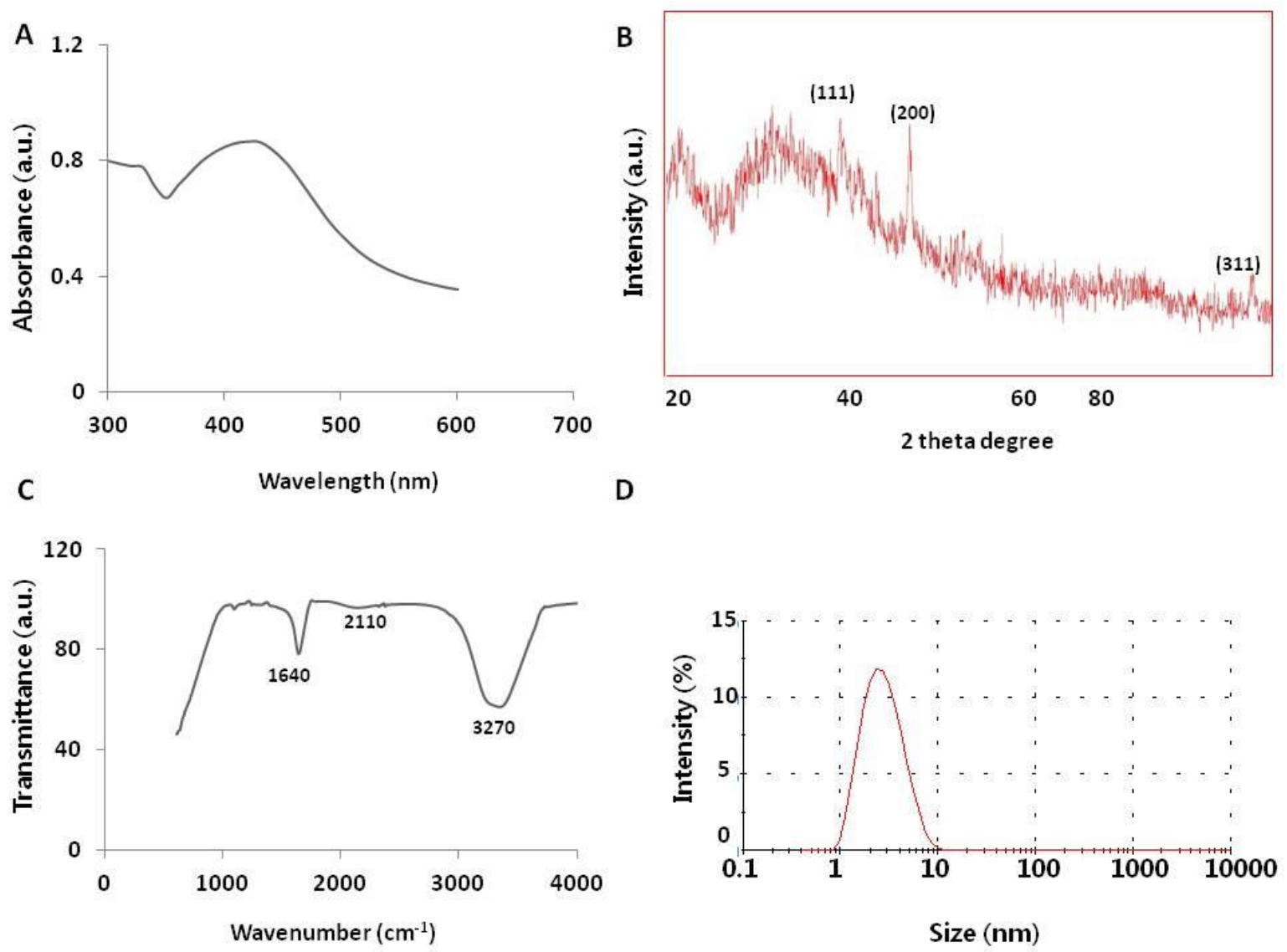

E

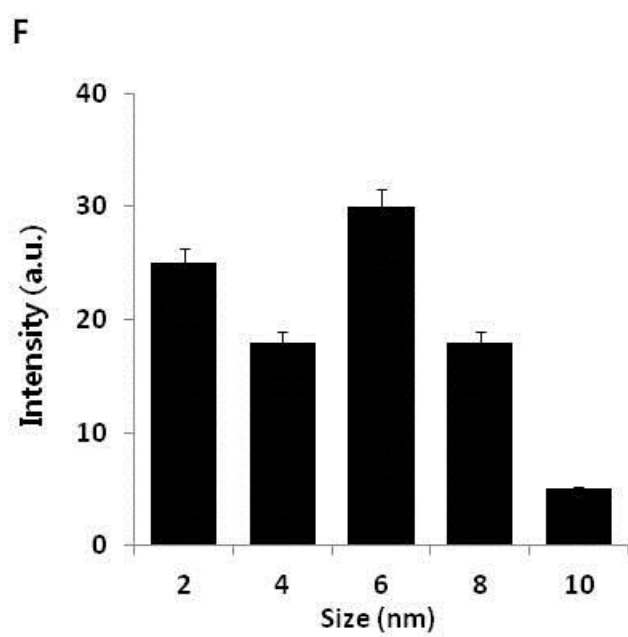

Figure 1. Synthesis and characterization of silver nanoparticles (AgNPs). (A) Ultraviolet-visible (UV-vis) spectra of AgNPs. (B) X-ray diffraction (XRD) pattern of AgNPs. (C) Fourier-transform infrared (FTIR) spectra of AgNPs. (D) Size distribution analysis of AgNPs using dynamic light scattering (DLS). (E) TEM images of AgNPs. (F) Particle size distributions from TEM images. The diameter of AgNPs was determined from more than 200 particles.

\subsection{Effect of AgNPs on Cell Viability and Proliferation of HCT116 and HT-29 Cells}

To evaluate the potential toxicity effects of AgNPs, HCT116 and HT-29 cells were treated with various concentrations of AgNPs $(2-10 \mu \mathrm{g} / \mathrm{mL})$, and cell viability was determined based on 
mitochondrial activity. After $24 \mathrm{~h}$ of exposure, mitochondrial activity was decreased in response to a concentration of $2 \mu \mathrm{g} / \mathrm{mL}$, and the cell viability rapidly decreased when AgNP concentrations were increased from 2 to $10 \mu \mathrm{g} / \mathrm{mL}$ (Figure $2 \mathrm{~A}$ ). At $4-10 \mu \mathrm{g} / \mathrm{mL}$ AgNPs, mitochondrial activity significantly decreased to $50 \%$ for cells exposed to 5 and $4 \mu \mathrm{g} / \mathrm{mL}$ AgNPs in HCT116 and HT-29 cells, respectively. At this time point and dose, mitochondrial activity was significantly reduced in AgNP-exposed cells. Miethling-Graff et al. [34] reported the size-dependent (10, 20, 40, 60, and $100 \mathrm{~nm}$ ) effects of AgNPs in the human LoVo cell line. The authors found that cellular uptake and toxicity were regulated by size, and smaller particles easily penetrated the cells, while larger particles such as 100-nm particles did not. Similarly, para-hydroxybenzoate tetrahydrate (SPHT)-assisted synthesis of AgNPs showed dose- and time-dependent inhibition of cell viability in the human colon cancer cell lines, HCT15 and HT-29. Cells exposed to SPHT-AgNPs $(8 \mu \mathrm{g} / \mathrm{mL})$ displayed $50 \%$ inhibition of cell proliferation after $24 \mathrm{~h}$ of treatment [35]. Plant-assisted AgNPs showed greater anti-proliferative effects against HCT116 cells at a minimum concentration of approximately $450 \mathrm{nM}$ than synthetic $\mathrm{AgNPs}$ and $\mathrm{AgNO}_{3}$ [36]. Abutilon indicum-assisted AgNPs showed dose-dependent anti-proliferative effects against COLO 205 (human colon cancer) and MDCK (normal) cells [37].
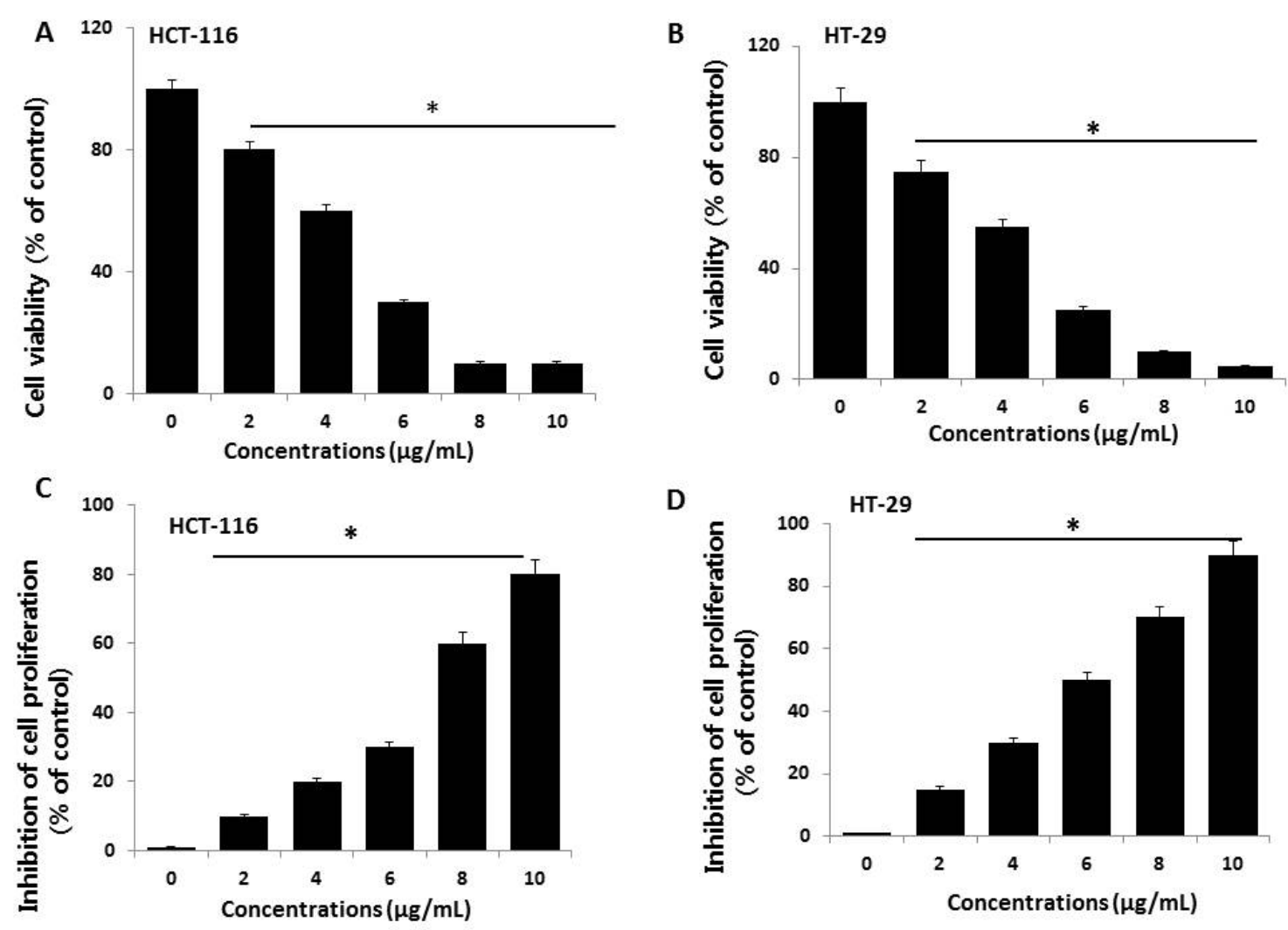

Figure 2. Cell viability and proliferation assessment of AgNPs in HCT116 and HT-29 cells. (A,B) Viability of HCT116 and HT-29 cells was determined $24 \mathrm{~h}$ after exposure to different concentrations of AgNPs with a Cell Counting Kit-8 (CCK-8) assay. The results are expressed as the mean \pm standard deviation of three independent experiments. A significant difference was observed from $2 \mu \mathrm{g} / \mathrm{mL}$ onward. (C,D) Cell proliferation of HCT116 and HT-29 was performed using a BrdU cell proliferation assay. The results are expressed as the mean \pm standard deviation of three independent experiments. A significant difference was observed from $2 \mu \mathrm{g} / \mathrm{mL}$ onward. There was a significant difference in the ratio for AgNP-treated cells compared to untreated cells, determined by a Student's $t$-test $\left({ }^{*} p<0.05\right)$. 
Next, we examined the dose-dependent effects of various concentrations of AgNPs on cell proliferation by measuring BrdU incorporation during DNA synthesis. HCT116 cells exposed to various concentrations of AgNPs showed a significantly reduced proliferation rate compared to control cells, which agrees with the results of the cell viability analysis (Figure 2B). The proliferation rate, relative to non-exposed control cells, was evaluated after a 24-h exposure to various concentrations of AgNPs. The results revealed that the proliferation rate decreased with increasing doses. Similarly, AgNPs exhibited anti-proliferative effects in various types of cancer cells including human breast cancer cells [8,38], human lung cancer cells [17], human ovarian cancer cells [15], and human neuroblastoma cells [39]. Among these two tested cell lines, HT-29 seems to be sensitive compared to HCT116 cells. Therefore, further study focused on HCT116 cells.

\subsection{AgNPs Increase Cytotoxicity in HCT116 Cells}

The lactate dehydrogenase (LDH) leakage assay is a well-known cytotoxicity assay for measuring cytotoxicity based on the leakage of intracellular molecules through impaired plasma membranes. LDH is a soluble cytoplasmic enzyme present in nearly all cells, and it is released into the extracellular space when the plasma membrane is damaged $[16,40,41]$. To detect the leakage of LDH into cell culture medium, the cells were treated with different concentrations of AgNPs $(2-10 \mu \mathrm{g} / \mathrm{mL})$ for $24 \mathrm{~h}$, and then, leakage was measured as the amount of formazan product formed using standard spectroscopy. As expected, increasing doses of AgNPs showed that leakage of LDH was directly proportional to the dosage of AgNPs and increased cytotoxicity (Figure 3A), indicating that cells undergoing accidental cell death upon exposure to AgNPs swell and lose membrane integrity before shutting down and releasing their intracellular contents into the surrounding environment. These results indicate that high concentrations of AgNPs damage cellular membrane integrity. Our results agree with those of previous reports showing that AgNPs induce leakage of LDH in different type of cancer cells and non-cancer cells, including human breast cancer cells [14,38], human lung cancer cells [17], human ovarian cancer cells [16], human neuroblastoma cells [39], human microvascular endothelial cells [42], male somatic cells, spermatogonial stem cells [8], and neural stem cells [43]. Collectively, the results suggest that reduced viability was observed in HCT116 cells exposed to AgNPs, which correlates with the increased leakage of LDH and significantly strong cytotoxicity.

Although several assays are established for measuring cell viability and toxicity, proteolytic activities associated with cell death or viability are very sensitive and depend on membrane integrity, acting as cytotoxic agents. Therefore, we measured the impact of AgNPs on dead-cell protease activity in HCT116 cells exposed to various concentrations of AgNPs; the cell viability was calculated according to the manufacturer's instructions (Promega Corp., G9292, WI, USA) and a previously reported method [44]. HCT116 cells treated with AgNPs showed reduced viability with increasing concentrations of AgNPs (Figure 3B). These results suggest that the viability of HCT116 cells was profoundly reduced, which agrees with the results of the cell viability and LDH leakage assays. 
A

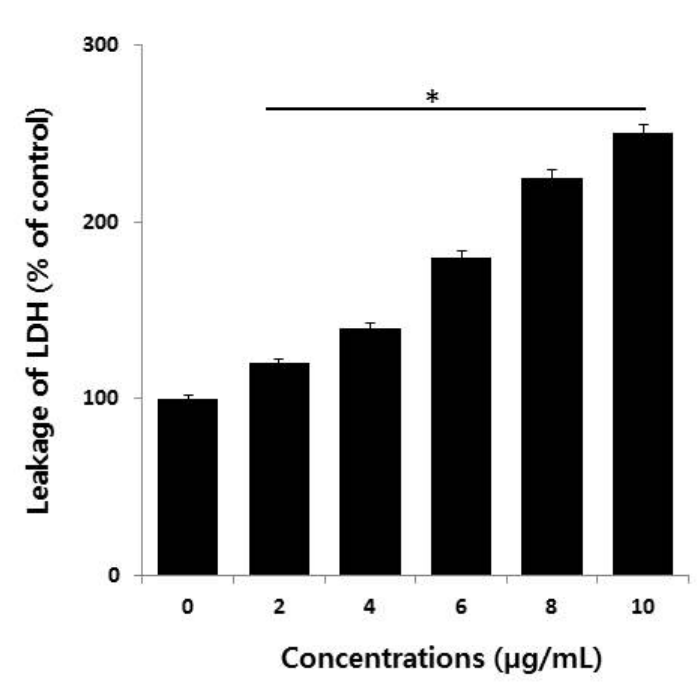

B

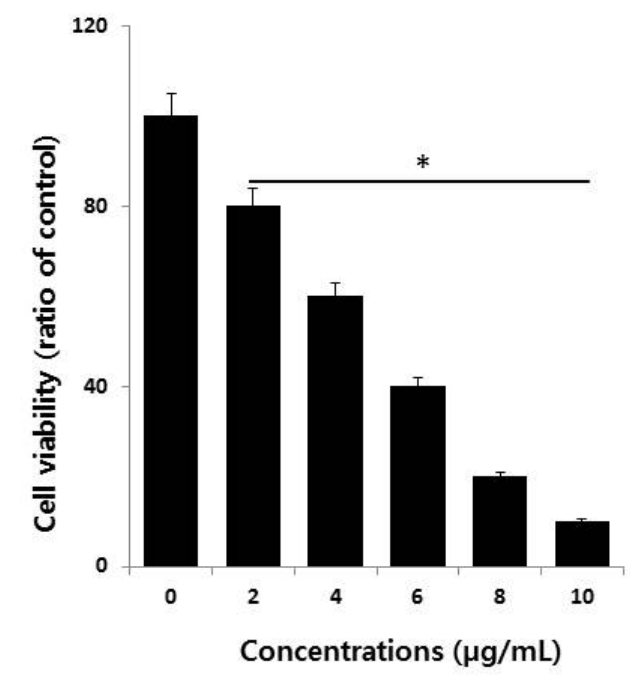

Figure 3. Measurement of lactate dehydrogenase (LDH) leakage and cell-death protease activity. (A) LDH activity was measured at $490 \mathrm{~nm}$ using an LDH cytotoxicity kit. (B) The level of dead-cell protease was determined using the CytoTox-Glo cytotoxicity assay. The results are expressed as the mean \pm standard deviation of three independent experiments. There was a significant difference in the ratio for AgNP-treated cells compared to untreated cells, determined by a Student's $t$-test $\left({ }^{*} p<0.05\right)$.

\subsection{Effect of AgNPs on ROS Generation and Malondialdehyde (MDA)}

Ag ions play an important role in catalyzing ROS production in the presence of oxygen species, and AgNPs can induce oxidative stress in a variety of cellular systems by generating ROS, including in human lung cancer A549 cells [45,46], human ovarian cancer cells [16], and human neuroblastoma cells [39]. To examine the effect of AgNPs on ROS generation, HCT116 cells were treated with various concentrations of AgNPs for $24 \mathrm{~h}$, and then, ROS generation was measured in a an $\mathrm{H}_{2}$ DCF-DA assay. After $24 \mathrm{~h}$ of exposure, increasing concentrations of AgNPs $(2-10 \mu \mathrm{g} / \mathrm{mL})$ significantly increased ROS levels at concentrations above $6 \mu \mathrm{g} / \mathrm{mL}$ compared to the control (Figure $4 \mathrm{~A}$ ). ROS levels generated in response to AgNPs treatment were significantly higher than those in normal cells. At all tested concentrations, the most pronounced effects were observed at higher concentrations, showing up to 2-3-fold higher ROS levels. Miethling-Graff et al. [34] reported the size-dependent toxicity by generation of ROS in the human LoVo cell line, in which smaller-sized particles produced more ROS than larger-sized particles. Mata et al. [37] found that COLO205 cells exposed to AgNPs produced significant levels of ROS compared to untreated control cells. The major anti-cancer effect of AgNPs involves the induction of apoptosis and autophagy through various molecular mechanisms, including by significantly decreasing cell viability and motility, impairing matrix metalloproteinase- 2 and -9 activity, and promoting ROS generation, all of which induce cell death through apoptosis and autophagy [47]. The potential toxicity of AgNPs depends on ROS generation and depletion of the antioxidant defense systems, as well as the loss of mitochondrial membrane potential [44]. The influence of the surface coating of AgNPs by various biological reducing agents, such as bacterial cellular extracts and fungal cellular extracts, affects ROS generation in human breast cancer cells. For example, fungal extract-mediated synthesis of AgNPs induced more ROS generation than AgNPs synthesized using bacterial cellular extracts, suggesting that coating materials influence ROS generation, and ultimately, cell death [14]. In contrast, chitosan-derived polysaccharide-coated AgNPs showed antimicrobial activity, with no toxicity observed against eukaryotic cells [48]. Collectively, our findings suggest that AgNPs generate significant levels of ROS, which may induce apoptosis by disturbing homeostasis between the oxidant and antioxidant enzyme systems to alter cellular redox [44]. 
ROS-mediated oxidative stress is a common mechanism of cell death, and it is known to regulate various cellular functions such as cellular proliferation, apoptosis, and necrosis depending on the level of levels of oxidant and antioxidant enzymes [49]. Exposure of cancer cells to chemotherapeutic agents, cytotoxic agents, and nanoparticles creates an imbalance between pro-oxidants and antioxidants. Thus, we analyzed the level of MDA in HCT116 cells treated with various concentrations of AgNPs for $24 \mathrm{~h}$. The results indicated that AgNPs increased the level of MDA; moreover, increasing concentrations of AgNPs significantly increased the MDA levels in human prostate cancer cells (Figure 4B). Gliga et al. [50] reported that long-term exposure of AgNPs in human lung cells upregulated the gene expression of antioxidant enzymes such as glutathione-S-transferase enzymes involved in clearing lipid peroxidation products. Lipid peroxidation is a source of free-radical formation and a hallmark of ferroptosis, which is emerging as a form of regulated cell death. Collectively, our findings suggest that AgNPs induce oxidative stress through the oxidation of lipid biomolecules.

A

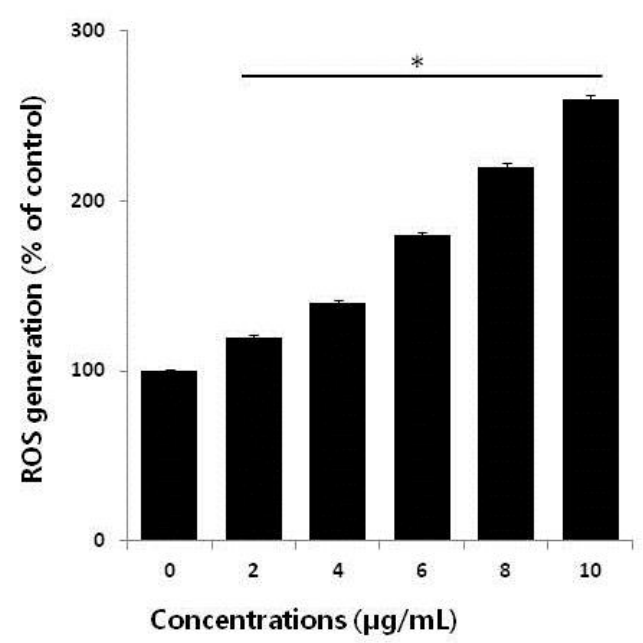

B

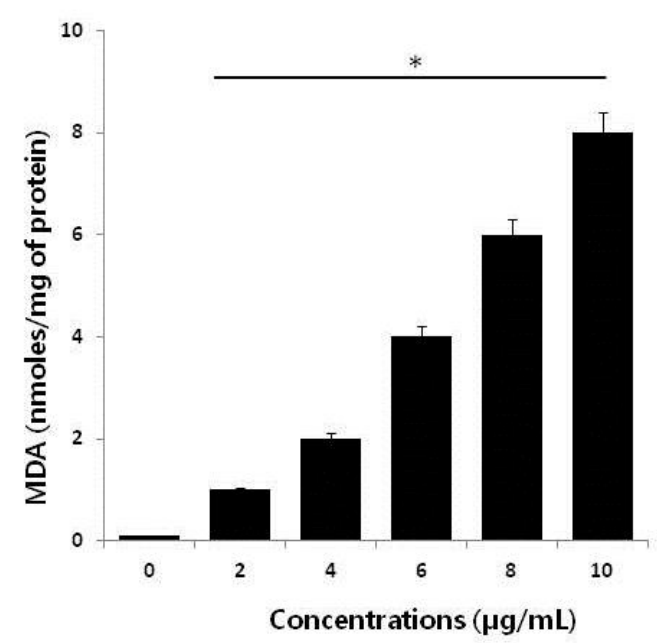

Figure 4. Effect of AgNPs on reactive oxygen species (ROS) generation. (A) HCT116 cells were treated with or without AgNPs for $24 \mathrm{~h}$, and ROS generation was measured using $2^{\prime}, 7^{\prime}$-dichlorodihydrofluorescein diacetate (DCFH-DA). (B) HCT116 cells were treated with AgNPs for $24 \mathrm{~h}$. After incubation, the cells were harvested and washed twice with ice-cold phosphate-buffered saline (PBS) solution. The cells were collected, and disrupted by ultrasonication for $5 \mathrm{~min}$ on ice. Lipid peroxidation (LPO) was determined via the reaction of malondialdehyde (MDA) with thiobarbituric acid to form a colorimetric $(532 \mathrm{~nm}$ )/ fluorometric (excitation and emission wavelengths of 532 and $553 \mathrm{~nm}$, respectively) product, whose quantity was proportional to that of MDA. The results are expressed as the mean \pm standard deviation of three independent experiments. There was a significant difference in the ratio for AgNP-treated cells compared to untreated cells, determined by a Student's $t$-test $(* p<0.05)$.

\subsection{AgNPs Induce Mitochondrial Dysfunction and Reduce ATP Generation in HCT116 Cells}

Loss of mitochondrial function is a major determinant and indicator of cell death, which can be assessed by monitoring changes in mitochondrial membrane potential (MMP). We measured MMP in AgNP-treated HCT116 cells using cationic fluorescent dyes [47]. To determine the influence of AgNPs on MMP, HCT116 cells were treated with various concentrations of AgNPs for $24 \mathrm{~h}$, and then, the MMP status was measured. The treated cells showed remarkable differences compared to control cells (Figure 5A). These results indicate that AgNP incubation for $24 \mathrm{~h}$ severely reduced MMP, and that the reductions in cell viability and toxicity were associated with the loss of MMP and increased accumulation of ROS. Previous studies reported that increased ROS generation leads to 
mitochondria-dependent cell death pathways through the formation of mitochondrial permeability transition pores [51,52]. Mitochondrial membrane depolarization is known to increase following ROS production, which is major factor activating intrinsic cell-death pathways [16,46]. Therefore, the loss of MMP supports mitochondrial depolarization as a primary mechanism of AgNP-induced toxicity, involving one or more signaling cascades with crosstalk between the mitochondrion and other cellular components $[45,53,54]$. As a result of cellular uptake of AgNPs by HCT116 cells, the cytotoxicity was increased via an alteration of MMP. The change in MMP was further confirmed using flow cytometry analysis of AgNP-treated HCT116 cells using JC-1 dye. The mitochondrial stain, JC-1, can spontaneously aggregate, emitting red fluorescence at high membrane potential in healthy cells, whereas in the apoptotic cells, JC-1 remains in the form of green fluorescent monomers due to mitochondrial membrane depolarization. The change in MMP in HCT116 cells induced by AgNPs is shown in Figure 5B. This indicates that the induction of apoptosis by AgNPs is associated with the mitochondrial pathway.

A
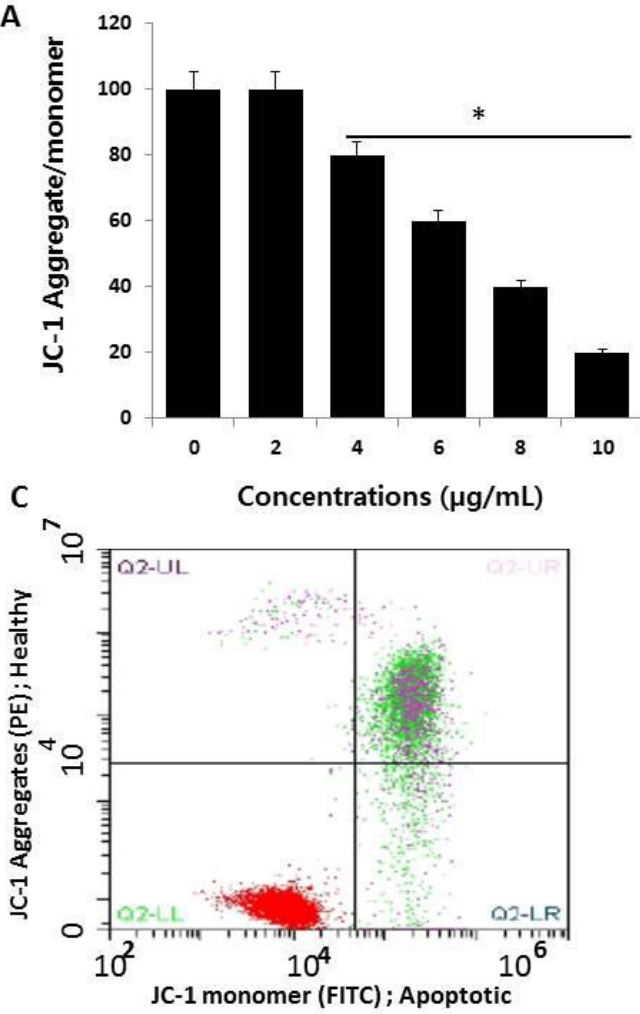

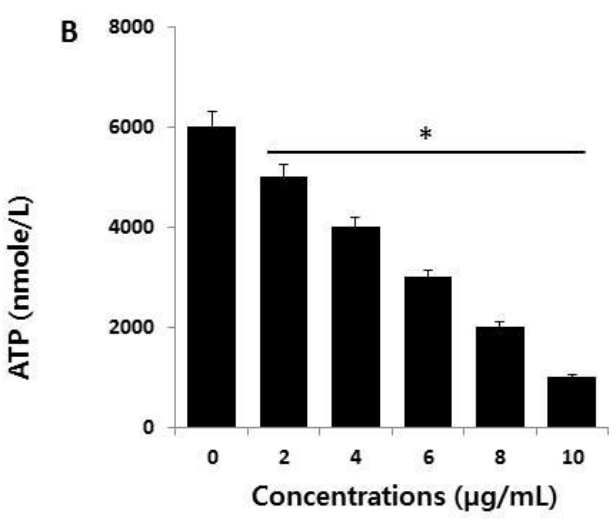

B 8000

Figure 5. Measurement of mitochondrial membrane potential (MMP) and ATP. (A) HCT116 cells were treated with AgNPs for $24 \mathrm{~h}$. The change in MMP was determined using the cationic fluorescent dye, JC-1 (Molecular Probes, Eugene, OR, USA). (B) Flow cytometric analysis (FACS) of the mitochondrial membrane potential using the JC-1 dye in HCT116 cells treated with AgNPs (half maximal inhibitory concentration ( $\left.\mathrm{IC}_{50}\right) 3 \mu \mathrm{g} / \mathrm{mL}$ ) for $24 \mathrm{~h}$. (C) The ATP level was measured according to the manufacturer's instructions (Sigma-Aldrich, St. Louis, MO, USA; Catalog Number MAK135) in HCT116 cells exposed to AgNPs for $24 \mathrm{~h}$. The results are expressed as the mean \pm standard deviation of three independent experiments. There was a significant difference in the ratio of AgNP-treated cells compared to untreated cells, determined by a Student's $t$-test $\left({ }^{*} p<0.05\right)$.

Next, to confirm whether the loss of MMP influences ATP production in AgNP-treated cells, we measured ATP levels in both AgNP-treated and untreated cells. It is well known that the mitochondria provide most of the energy required for proper cellular function, and damage to the mitochondria results in decreased or inefficient energy production, potentially affecting ATP 
production or ATP-dependent cellular mechanisms [55]. As expected, AgNP-treated cells showed significantly lower levels of ATP production compared to controls (Figure 5B). Interestingly, increasing concentrations of AgNPs led to decreased ATP production. The results showed that there was a direct linear relationship between AgNP concentration and ATP production. Thus, the cells appear to be sensitive to mitochondrial toxicants such as AgNPs, which is similar to drug-induced mitochondrial poisoning-inherited mitochondrial diseases [56].

\subsection{AgNPs Induce Apoptosis}

High ROS levels induce oxidative stress and cell death [57]. Previously, our lab and other research groups showed that AgNP-induced cytotoxicity primarily results from oxidative stress which, in turn, induces cell death through activation of the intrinsic pathway of apoptosis, autophagy, or both $[15,39,46,53]$. We examined whether AgNP-induced cell death occurs via apoptosis using terminal deoxynucleotidyl transferase-mediated dUTP nick end labeling (TUNEL) analysis. Oxidative stress is a crucial factor for inducing apoptosis in cancer cells through various mechanisms causing macromolecular damage, such as lipid peroxidation, DNA fragmentation, protein denaturation, and mitochondrial dysfunction [53]. ROS can act as signal molecules to promote cell-cycle progression and induce oxidative DNA damage [51,58]. Measurement of DNA fragmentation appears to be the best technique for evaluating AgNP-induced apoptosis. To detect apoptotic features induced by AgNPs, HCT116 cells were treated with the half maximal inhibitory concentration $\left(\mathrm{IC}_{50}\right)$ of AgNPs, and a DNA-fragmentation assay was conducted. The results, shown in Figure 6, revealed a significant number of positively labeled cells, representing apoptotic DNA fragmentation. In control cultures, few or no apoptotic cells were observed. Characteristic features of apoptosis include cell shrinkage, chromatin condensation, extensive plasma membrane bleb, and separation of cell fragments into apoptotic bodies [59]. Cancer cell lines treated with AgNPs exhibited the same "laddering" pattern as evidenced by DNA fragmentation observed in this study [14]. During DNA fragmentation, the deposition of silver particles inside the nucleus may affect DNA and cell division, and nanoparticles may induce dose-dependent DNA damage, chromosomal aberrations, and errors in chromosome segregation, as well as the formation of sister chromatic exchanges [60]. Our results are consistent with those of previous studies showing that cancer cells treated with AgNPs induce the production of micronuclei [51]. Therefore, we found that AgNPs induce DNA fragmentation, and eventually, induce apoptosis in HCT116 cells.

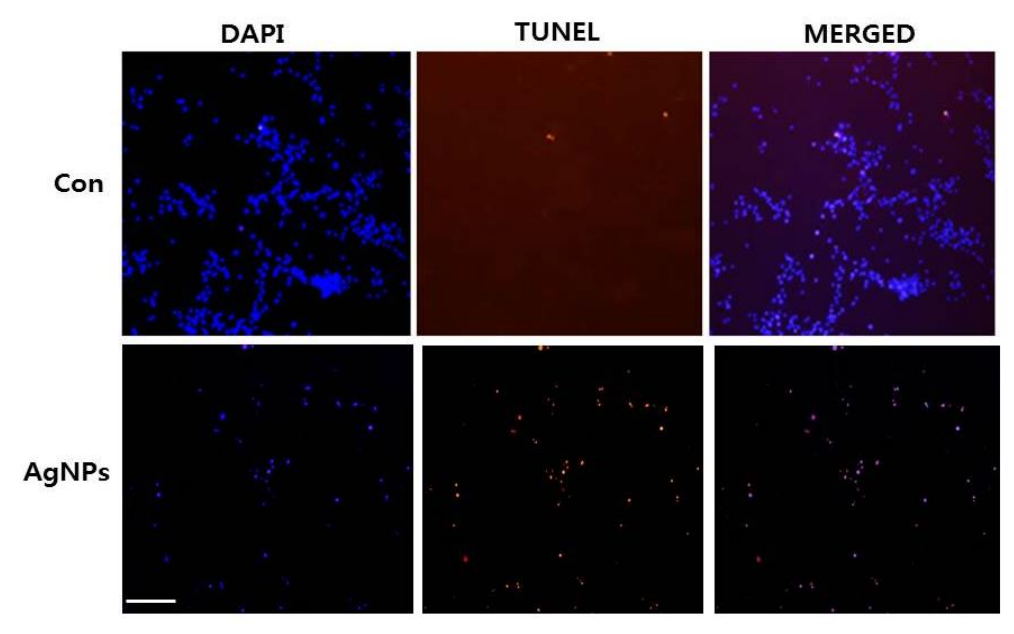

Figure 6. AgNP-induced apoptosis in HCT116 cells. HCT116 cells were treated with AgNPs for $24 \mathrm{~h}$. Next, cell apoptosis was assessed using the terminal deoxynucleotidyl transferase-mediated dUTP nick end labeling (TUNEL) assay; nuclei were counterstained with 4',6-diamidino-2-phenylindole (DAPI). Representative images show apoptotic (fragmented) DNA (red staining) and the corresponding cell nuclei (blue staining). Original magnification, $\times 100$; scale bar, $100 \mu \mathrm{m}$. 


\subsection{AgNP Treatment Impairs Expression of Genes Involved in Mitochondrial Function and Cell Apoptosis}

To identify which genes were altered by AgNP treatment, cells were treated with the $50 \%$ inhibitory concentration of AgNPs $(5 \mu \mathrm{g} / \mathrm{mL})$, and then, we performed RNA-Seq analysis and generated $\sim 26$ million reads of RNA-Seq data in each sample. As shown in Figure 7A, 256 upregulated and 174 downregulated genes were identified with cut-off values of fragments per kilobase of transcript per million mapped reads (FPKM) $>2$, and fold changes $>2$ in AgNP-treated HCT116 cells. Representative upregulated (CYP1A1 and CYP1B1) and downregulated genes (CCNB1 and CCNB2) upon AgNP treatment are illustrated in Figure 7B. Both upregulated and downregulated genes were subjected to Gene Ontology (GO) term analysis to identify biological processes. The highest-ranked biological processes included oxidation-reduction processes, responses to drug, cellular responses to cadmium ions, and regulation of the cell cycle (Figure 7C). Next, each up- or downregulated gene was subjected to GO term analysis. The data further support our findings of the cellular and molecular analyses. As shown in Figure 7D,E, the most highly ranked biological process with upregulated genes was oxidation-reduction, whereas the most highly ranked biological process with downregulated genes was regulation of the cell cycle. Particularly, the oxidation-reduction-related genes code for cytochrome P450 monooxygenases such as CYP1A1 and CYP1B1. The cytochrome P450 enzymes are mainly distributed in the endoplasmic reticulum and mitochondria, and they catalyze many reactions involved in steroid and cholesterol synthesis and drug metabolism. A previous study showed that mitochondrial CYP1B1 is involved in melatonin-induced apoptosis in the SH-SY5Y neuroblastoma cell line. It is well known that melatonin has dual functions in apoptosis; anti-tumorigenic effects were observed in some cancer cells by promoting apoptosis, whereas no or little effect was observed in normal cells. Consistent with our data, forced expression of CYP1A1 in cancer cells led to apoptosis. Asik et al. [61] also showed that administration of a high dose of cobalt ferrite magnetic nanoparticles to human breast cancer cell lines caused apoptosis with elevations in CYP1A1 and CYP1B1 expression. Interestingly, genes linked to aging were selectively upregulated in AgNP-treated cells. In contrast, G2/M check-point regulators including CCNB1 and CCNB2 were found in the biological process of regulation of the cell cycle with downregulated genes. Multiple bio-grade chemicals were shown to block cell-cycle progression by repressing CCNB1 or CCNB2 gene expression, eventually leading to cell apoptosis. 


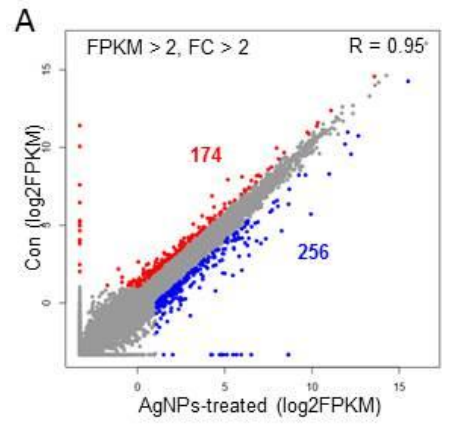

B
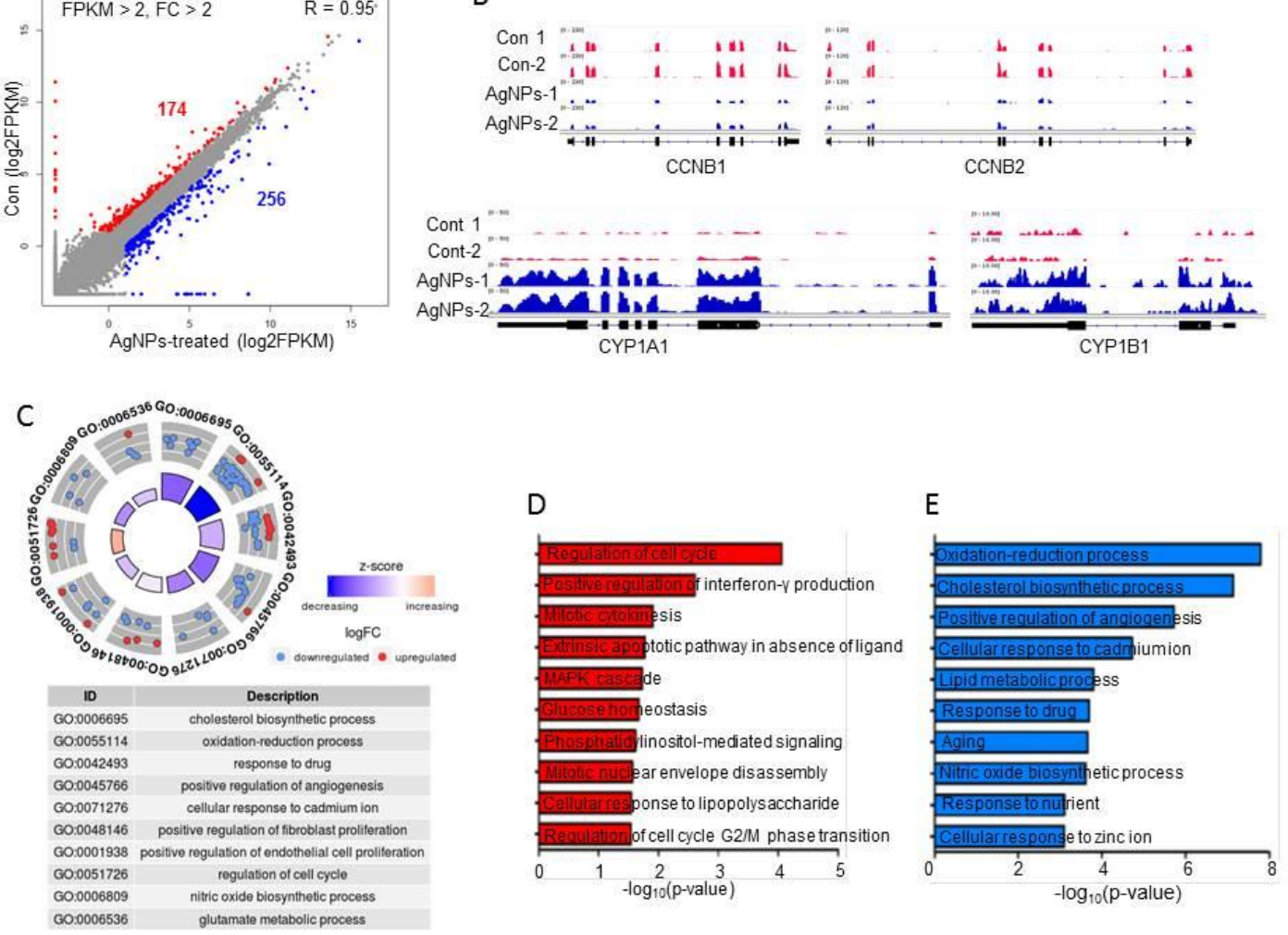

Figure 7. Impact of AgNPs on gene expression. (A) Scatter plot showing up- and downregulated genes in AgNP-treated HCT116 cells. The $\log _{2}$ fragments per kilobase of transcript per million mapped reads (FPKM) values were used for plotting. Red and blue dots indicate downregulated and upregulated genes in AgNP-treated HCT116 cells, respectively. Cut-off: FPKM >2 and fold change $>2$. (B) Representative IGV images of down- (CCNB1 and CCNB2) and upregulated (CYP1A1 and CYP1B1) genes. (C) Gene Ontology (GO) term analysis using both up- and downregulated genes. Each red (downregulated) or blue (upregulated) dot represents one gene belonging to each term. (D,E) bar graphs showing GO terms of individual up- and downregulated genes.

\subsection{AgNP Treatment Dysregulates Multiple Biological Pathways}

Next, to examine the biological pathways associated with the differentially expressed genes, KEGG pathway analysis was performed. As shown in Figure 8A,B, p53 signaling and cell-cycle pathways were detected for downregulated genes, whereas mineral absorption and metabolic pathways were detected for upregulated genes. Interestingly, the p53 pathway was found in both up- and downregulated genes. An S/G2 phase-specific gene, GTSE1, which is an AgNPs-mediated repressed gene in the p53 pathway, promotes the degradation of p53 by forming a protein complex. Additionally, elevation of GTSE1 gene expression was detected in multiple cancer types including lung cancer, myeloma cells, and gastric cancer. GADD45G, a downstream regulator of p53, was shown to be downregulated in multiple cancer types. Hsu et al. [62,63] showed that induction of GADD45G by treatment with a natural compound, cucurbitacin E, caused G2/M arrest in malignant glioma GBM 8401 cells. Our KEGG analysis identified GADD45G in the p53 pathway with genes upregulated by AgNPs. Our results agree with those of Gurunathan et al. [15] showing involvement of p53 and the critical role of p53 upregulation in AgNP-mediated cell death in human breast cancer cells. Therefore, our genome-wide study suggests that the tumor-suppressive role of AgNPs is mediated via combinatorial effects of cell apoptosis by DNA damage, and mitochondrial dysfunction and cell cycle arrest by aberrant regulation of p53 effector proteins. 

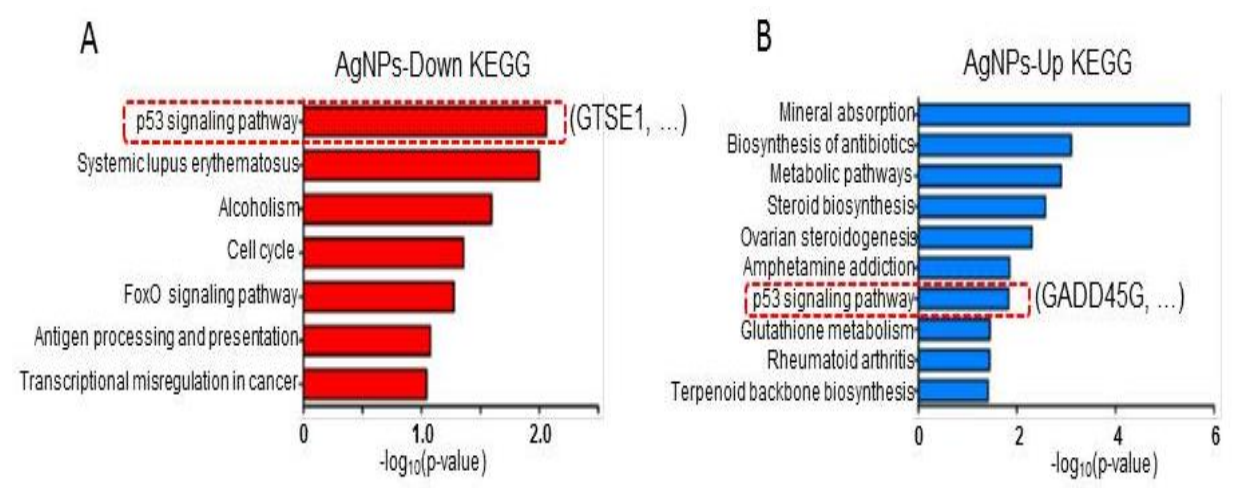

Figure 8. KEGG pathway analysis. (A,B) Bar graphs showing biological pathways associated with down- and upregulated genes following AgNP administration. The p53 pathway is highlighted with a representative gene in each case.

\section{Materials and Methods}

\subsection{Materials}

HCT116 colorectal cell lines were purchased from the Korean Cell Line Bank (Seoul, Korea). Penicillin-streptomycin, trypsin-EDTA, Dulbecco's modified Eagle's medium (DMEM), and 1\% antibiotic-antimycotic were obtained from Life Technologies/Gibco (Grand Island, NY, USA). Fetal bovine serum and the in vitro toxicology assay kit were purchased from Sigma-Aldrich (St. Louis, MO, USA). Silver nitrate and all other chemicals were purchased from Sigma-Aldrich unless otherwise stated.

\subsection{Synthesis and Characterization of AgNPs}

Synthesis and characterization of AgNPs was carried out as described previously [17]. Synthesis of AgNPs was carried out using naringenin (NAR) dissolved in dimethyl sulfoxide. AgNPs were synthesized by incubating $50 \mu \mathrm{M}$ NAR in $100 \mathrm{~mL}$ of water containing $2 \mathrm{mM} \mathrm{AgNO}_{3}$ at $37^{\circ} \mathrm{C}$ for $1 \mathrm{~h}$. The color change from pale yellow to dark yellowish-brown was attributed to the formation of AgNPs in the reaction mixture.

\subsection{Cell Viability and Cell Proliferation}

Cell viability was measured using a Cell Counting Kit-8 (CCK-8; CK04-01, Dojindo Laboratories, Kumamoto, Japan). Cell proliferation was determined according to the manufacturer's instructions (Roche, Basel, Switzerland). Briefly, HCT116 cells were plated in 96-well flat-bottom culture plates containing various concentrations of AgNPs. After 24-h culture at $37^{\circ} \mathrm{C}$ and $5 \% \mathrm{CO}_{2}$ in a humidified incubator, CCK-8 solution $(10 \mu \mathrm{L})$ was added to each well, and the plate was incubated for another $2 \mathrm{~h}$ at $37^{\circ} \mathrm{C}$. Absorbance was measured at $450 \mathrm{~nm}$ using a microplate reader (Multiskan FC; Thermo Fisher Scientific, Inc., Waltham, MA, USA).

\subsection{Membrane Integrity}

The membrane integrity of HCT116 cell lines was evaluated using an LDH Cytotoxicity Detection Kit. Briefly, cells were exposed to various concentrations of AgNPs for $24 \mathrm{~h}$. Subsequently, $100 \mu \mathrm{L}$ of cell-free supernatant from each well was transferred in triplicate into the wells of a 96-well plate, and then, $100 \mu \mathrm{L}$ of the $\mathrm{LDH}$ reaction mixture was added to each well. After $3 \mathrm{~h}$ of incubation under standard conditions, the optical density of the final solution was determined at a wavelength of $490 \mathrm{~nm}$ using a microplate reader. 


\subsection{Assessment of Dead-Cell Protease Activity}

Dead-cell protease activity was assessed as previously described [44]. The cytotoxicity assay was used to evaluate the cytotoxic effects of AgNPs in HCT116 cells. Cytotoxicity was determined using the reaction of intracellular protease with a luminogenic peptide substrate (alanyl-alanylphenylalanyl-aminoluciferin). Luminescence was measured using a Luminescence Counter (Perkin Elmer, Waltham, MA, USA).

\subsection{Determination of Intracellular ROS}

HCT116 cells were treated with AgNPs for $24 \mathrm{~h}$. ROS were measured according to a previous method based on the intracellular peroxide-dependent oxidation of $2^{\prime}, 7^{\prime}$-dichlorodihydrofluorescein diacetate (DCFH-DA; Molecular Probes, Eugene, OR, USA) to form the fluorescent compound $2^{\prime}, 7^{\prime}$-dichlorofluorescein (DCF) $[45,46]$.

\subsection{Measurement of $M D A$}

Oxidative stress markers, such as malondialdehyde (MDA), were assayed according to each manufacturer's instructions. Briefly, the cells were cultured in $75-\mathrm{cm}^{2}$ culture flasks and exposed to various concentrations of AgNPs for $24 \mathrm{~h}$. The cells were harvested in chilled phosphate-buffered saline (PBS) by scraping and washing twice with saline, followed by centrifugation at $4{ }^{\circ} \mathrm{C}$ for $6 \mathrm{~min}$ at $1500 \mathrm{rpm}$. The cell pellet was sonicated at $15 \mathrm{~W}$ for $10 \mathrm{~s}$ (three cycles) to obtain the cell lysate. The resulting supernatant was stored at $-70{ }^{\circ} \mathrm{C}$ until analysis.

\subsection{JC-1 Assay}

HCT116 cells were treated with AgNPs for $24 \mathrm{~h}$. Changes in mitochondrial membrane potential (MMP) were evaluated using the cationic fluorescent dye, JC-1 (Molecular Probes). Fluorescence of JC-1 aggregates and JC-1 monomers was measured at an excitation wavelength of $488 \mathrm{~nm}$ and emission wavelengths of 583 and $525 \mathrm{~nm}$ using a Gemini EM fluorescence microplate reader (Molecular Devices, Sunnyvale, CA, USA).

\subsection{Measurement of ATP}

The ATP level was measured according to the manufacturer's instructions (Sigma-Aldrich; Catalog Number MAK135) in HCT116 cells exposed to various concentrations of AgNPs for $24 \mathrm{~h}$.

\subsection{TUNEL Analysis}

To detect apoptotic cells in groups treated with AgNPs $(5 \mu \mathrm{g} / \mathrm{mL})$, the terminal deoxynucleotidyl transferase-mediated dUTP nick end labeling (TUNEL) method was employed using an in situ detection kit (Promega, Madison, WI, USA) according to the manufacturer's instructions. HCT116 cells were plated in six-well plates $\left(2 \times 10^{5}\right.$ cells per well) and incubated with AgNPs $(5 \mu \mathrm{g} / \mathrm{mL})$ for $24 \mathrm{~h}$, and then, cell apoptosis was quantified using TUNEL analysis. Samples were evaluated under a Nikon Eclipse E400 fluorescence microscope (Nikon 40× Plan 40/0.65, Tokyo, Japan). Differences between the number of TUNEL-positive cells in the control and experimental samples were statistically analyzed.

\subsection{RNA-Seq and Downstream Bioinformatics Analysis}

Total RNA was extracted using TRIzol reagent following the manufacturer's instructions (Thermo Fisher Scientific, Waltham, MA, USA). The quality of total RNA was evaluated using the Agilent 2100 bioanalyzer (Agilent Technologies, Santa Clara, CA, USA) with the RNA 6000 Nano LabChip kit. RNA-seq libraries were prepared using the Illumina ${ }^{\circledR}$ TruSeq stranded total RNA Library Prep Kit v2 (San Diego, CA, USA), and were sequenced using an Illumina ${ }^{\circledR}$ Hiseq2500 to obtain 150-base pair paired-end reads. The sequencing depth of each sample was $>20$ million reads. The reads were aligned with TopHat 2.0.13 to GRCh37 with default parameters, and were then assembled by Cufflink 
2.2.1 using Ensembl v75 annotations. Transcript abundance was measured in fragments per kb of exon per million fragments mapped (FPKM). Differentially expressed genes were identified at an FPKM $>2$ and fold change $>2$. The RNA-seq data are available on the GEO (GSE100687). The enrichment of biological processes and KEGG pathways was conducted using DAVID (v6.8) tool. The R package (v3.3.2) and GOplot package (version 1.0.2) were used to generate scatter plots and Gene Ontology terms, respectively. Integrative genomics viewer was used to visualize the expression patterns of representative genes.

\subsection{Statistical Methods}

Independent experiments were repeated at least three times, and the data are represented as the mean \pm standard deviation for all duplicates within an individual experiment. Data were analyzed using a $t$-test, or multivariate analysis, or one-way analysis of variance, followed by the Tukey test for multiple comparisons, to detect differences between groups, denoted by an asterisk, using the Graph-Pad Prism analysis software (GraphPad, Inc., La Jolla, CA, USA).

\section{Conclusions}

Despite considerable focus on the anti-cancer effects of AgNPs in recent years, studies of the potential effects and molecular mechanism of AgNPs in cancer are limited. Therefore, the aim of this study was to explore the effects of AgNP exposure on human colorectal cancer cells, and to investigate the molecular mechanism using RNA-Seq. The human HCT116 cell line was exposed to $2-10 \mu \mathrm{g} / \mathrm{mL}$ AgNPs $(6 \mathrm{~nm})$ for $24 \mathrm{~h}$ followed by various cellular assays and RNA-Seq analysis. To determine the potential anti-cancer effect of AgNPs, we synthesized AgNPs using naringenin, which is a flavonoid predominantly found in grapefruit. HCT116 cells exposed to AgNPs for $24 \mathrm{~h}$ exhibited significant loss of cell viability and proliferation in a dose-dependent manner. The $50 \%$ inhibitory concentrations of $5 \mu \mathrm{g} / \mathrm{mL}$ AgNPs remarkably increased LDH leakage, ROS generation, and MDA levels, and decreased dead-cell protease activity levels and ATP generation. These events led to cell death by impairing mitochondrial function and by inducing DNA damage. Furthermore, our study also demonstrated that AgNPs upregulate and downregulate the most highly ranked biological processes of oxidation-reduction and regulation of the cell cycle, respectively. Our KEGG analysis identified GADD45G in the p53 pathway with genes upregulated by AgNPs. Therefore, our results suggest that the tumor-suppressive role of AgNPs is mediated via combinatorial effects of cell apoptosis by DNA damage, and mitochondrial dysfunction and cell cycle arrest by aberrant regulation of p53 effector proteins. Transcriptomic analysis showed that a substantial number of genes, 256 upregulated and 174 downregulated, were differentially expressed following AgNPs exposure; significant effects were observed in genes associated with oxidation-reduction and regulation of the cell cycle. Downstream analysis of the transcriptomics data identified several affected pathways, including the p53 pathway. In conclusion, using a combination of RNA-Seq and functional assays, our study revealed that exposure of human CRC cells to AgNPs induces cell apoptosis via DNA damage, mitochondrial dysfunction, and cell-cycle arrest by aberrant regulation of p53 effector proteins. Moreover, gene-expression profiling methods, such as RNA-Seq, can be used to predict mechanisms of toxicity of AgNPs. GO analyses demonstrated the molecular mechanism of the anti-cancer effect of AgNPs. The present study showed that transcriptome analysis can provide insights into the molecular mechanism of the anti-cancer activity of biogenic AgNPs.

Author Contributions: S.G. came up with the idea and participated in the design, performed the synthesis and characterization of nanomaterials, performed the cellular assays, and wrote the manuscript. M.Q. prepared the samples for RNA-Seq analysis, and J.-H.K. analyzed the data along with the monitored data. K.H., H.Y., and C.P. performed the RNA-Seq and downstream bioinformatics analysis. All authors read and approved the final manuscript.

Funding: This work was supported by a grant from the Science Research Center (2015R1A5A1009701) of the National Research Foundation of Korea. 
Acknowledgments: This study was supported by the KU-Research Professor Program of Konkuk University.

Conflicts of Interest: The authors declare no conflict of interest.

\section{References}

1. Arnold, M.; Sierra, M.S.; Laversanne, M.; Soerjomataram, I.; Jemal, A.; Bray, F. Global patterns and trends in colorectal cancer incidence and mortality. Gut 2017, 66, 683-691. [CrossRef] [PubMed]

2. Navarro, M.; Nicolas, A.; Ferrandez, A.; Lanas, A. Colorectal cancer population screening programs worldwide in 2016: An update. World J. Gastroenterol. 2017, 23, 3632-3642. [CrossRef] [PubMed]

3. Marley, A.R.; Nan, H. Epidemiology of colorectal cancer. Int. J. Mol. Epidemiol. Genet. 2016, 7, $105-114$. [PubMed]

4. Kelly, C.; Bhuva, N.; Harrison, M.; Buckley, A.; Saunders, M. Use of raltitrexed as an alternative to 5-fluorouracil and capecitabine in cancer patients with cardiac history. Eur. J. Cancer 2013, 49, 2303-2310. [CrossRef] [PubMed]

5. Kanterman, J.; Sade-Feldman, M.; Biton, M.; Ish-Shalom, E.; Lasry, A.; Goldshtein, A.; Hubert, A.; Baniyash, M. Adverse immunoregulatory effects of 5FU and CPT11 chemotherapy on myeloid-derived suppressor cells and colorectal cancer outcomes. Cancer Res. 2014, 74, 6022-6035. [CrossRef] [PubMed]

6. Qasim, M.; Lim, D.-J.; Park, H.; Na, D. Nanotechnology for Diagnosis and Treatment of Infectious Diseases. J. Nanosci. Nanotechnol. 2014, 14, 7374-7387. [CrossRef] [PubMed]

7. De Matteis, V.; Cascione, M.; Toma, C.C.; Leporatti, S. Silver Nanoparticles: Synthetic Routes, In Vitro Toxicity and Theranostic Applications for Cancer Disease. Nanomaterials 2018, 8, 319. [CrossRef] [PubMed]

8. Zhang, X.-F.; Liu, Z.-G.; Shen, W.; Gurunathan, S. Silver Nanoparticles: Synthesis, Characterization, Properties, Applications, and Therapeutic Approaches. Int. J. Mol. Sci. 2016, 17, 1534. [CrossRef] [PubMed]

9. AbdelRahim, K.; Mahmoud, S.Y.; Ali, A.M.; Almaary, K.S.; Mustafa, A.E.-Z.M.A.; Husseiny, S.M. Extracellular biosynthesis of silver nanoparticles using Rhizopus stolonifer. Saudi J. Biol. Sci. 2017, 24, 208-216. [CrossRef] [PubMed]

10. De Lima, R.; Seabra, A.B.; Durán, N. Silver nanoparticles: A brief review of cytotoxicity and genotoxicity of chemically and biogenically synthesized nanoparticles. J. Appl. Toxicol. 2012, 32, 867-879. [CrossRef] [PubMed]

11. Gurunathan, S.; Lee, K.-J.; Kalishwaralal, K.; Sheikpranbabu, S.; Vaidyanathan, R.; Eom, S.H. Antiangiogenic properties of silver nanoparticles. Biomaterials 2009, 30, 6341-6350. [CrossRef] [PubMed]

12. Sriram, M.I.; Kanth, S.B.M.; Kalishwaralal, K.; Gurunathan, S. Antitumor activity of silver nanoparticles in Dalton's lymphoma ascites tumor model. Int. J. Nanomed. 2010, 5, 753-762. [CrossRef]

13. Guo, D.; Zhu, L.; Huang, Z.; Zhou, H.; Ge, Y.; Ma, W.; Wu, J.; Zhang, X.; Zhou, X.; Zhang, Y.; et al. Anti-leukemia activity of PVP-coated silver nanoparticles via generation of reactive oxygen species and release of silver ions. Biomaterials 2013, 34, 7884-7894. [CrossRef] [PubMed]

14. Gurunathan, S.; Han, J.W.; Eppakayala, V.; Jeyaraj, M.; Kim, J.-H. Cytotoxicity of biologically synthesized silver nanoparticles in MDA-MB-231 human breast cancer cells. Biomed Res. Int. 2013, 2013, 535796. [CrossRef] [PubMed]

15. Gurunathan, S.; Jeong, J.-K.; Han, J.W.; Zhang, X.-F.; Park, J.H.; Kim, J.-H. Multidimensional effects of biologically synthesized silver nanoparticles in Helicobacter pylori, Helicobacter felis, and human lung (L132) and lung carcinoma A549 cells. Nanoscale Res. Lett. 2015, 10, 35. [CrossRef] [PubMed]

16. Gurunathan, S.; Han, J.W.; Park, J.H.; Kim, E.; Choi, Y.-J.; Kwon, D.-N.; Kim, J.-H. Reduced graphene oxide-silver nanoparticle nanocomposite: A potential anticancer nanotherapy. Int. J. Nanomed. 2015, 10, 6257-6276. [CrossRef] [PubMed]

17. Han, J.; Gurunathan, S.; Jeong, J.-K.; Choi, Y.-J.; Kwon, D.-N.; Park, J.-K.; Kim, J.-H. Oxidative stress mediated cytotoxicity of biologically synthesized silver nanoparticles in human lung epithelial adenocarcinoma cell line. Nanoscale Res. Lett. 2014, 9, 459. [CrossRef] [PubMed]

18. Online, V.A.; Sahu, S.; Sinha, N.; Bhutia, S.K.; Majhi, M.; Mohapatra, S. Luminescent magnetic hollow mesoporous silica nanotheranostics for camptothecin delivery and multimodal imaging. J. Mater. Chem. B 2014, 3799-3808. [CrossRef] 
19. Jagannath, C.V.; Radheshyam, B.K. Potentiation of antiepileptic activity of phenytoin using $\beta$ carotene against maximal electroshock induced convulsions in mice. World J. Pharm. Pharm. Sci. 2017, 1574-1585. [CrossRef]

20. Look, M.; Bandyopadhyay, A.; Blum, J.S.; Fahmy, T.M. Application of nanotechnologies for improved immune response against infectious diseases in the developing world. Adv. Drug Deliv. Rev. 2010, 62, 378-393. [CrossRef] [PubMed]

21. Feliu, N.; Kohonen, P.; Ji, J.; Zhang, Y.; Karlsson, H.L.; Palmberg, L.; Nyström, A.; Fadeel, B. Next-Generation Sequencing Reveals Low-Dose Effects of Cationic Dendrimers in Primary Human Bronchial Epithelial Cells. ACS Nano 2015, 9, 146-163. [CrossRef] [PubMed]

22. Liu, Y.; Guo, Y.; Ma, C.; Zhang, D.; Wang, C.; Yang, Q. Transcriptome analysis of maize resistance to Fusarium graminearum. BMC Genom. 2016, 17, 477. [CrossRef]

23. Sun, Q.-L.; Zhao, C.-P.; Wang, T.-Y.; Hao, X.-B.; Wang, X.-Y.; Zhang, X.; Li, Y.-C. Expression profile analysis of long non-coding RNA associated with vincristine resistance in colon cancer cells by next-generation sequencing. Gene 2015, 572, 79-86. [CrossRef] [PubMed]

24. Morrissy, A.S.; Garzia, L.; Shih, D.J.H.; Zuyderduyn, S.; Huang, X.; Skowron, P.; Remke, M.; Cavalli, F.M.G.; Ramaswamy, V.; Lindsay, P.E.; et al. Divergent clonal selection dominates medulloblastoma at recurrence. Nature 2016, 529, 351-357. [CrossRef] [PubMed]

25. Cong, L.; Ran, F.A.; Cox, D.; Lin, S.; Barretto, R.; Habib, N.; Hsu, P.D.; Wu, X.; Jiang, W.; Marraffini, L.A.; et al. Multiplex Genome Engineering Using CRISPR/Cas Systems. Science 2013, 339, 819-823. [CrossRef] [PubMed]

26. Kanno, S.; Shouji, A.; Hirata, R.; Asou, K.; Ishikawa, M. Effects of naringin on cytosine arabinoside (Ara-C)-induced cytotoxicity and apoptosis in P388 cells. Life Sci. 2004, 75, 353-365. [CrossRef] [PubMed]

27. Song, H.M.; Park, G.H.; Eo, H.J.; Lee, J.W.; Kim, M.K.; Lee, J.R.; Lee, M.H.; Koo, J.S.; Jeong, J.B. Anti-Proliferative Effect of Naringenin through p38-Dependent Downregulation of Cyclin D1 in Human Colorectal Cancer Cells. Biomol. Ther. (Seoul) 2015, 23, 339-344. [CrossRef] [PubMed]

28. Sahu, N.; Soni, D.; Chandrashekhar, B.; Satpute, D.B.; Saravanadevi, S.; Sarangi, B.K.; Pandey, R.A. Synthesis of silver nanoparticles using flavonoids: Hesperidin, naringin and diosmin, and their antibacterial effects and cytotoxicity. Int. Nano Lett. 2016, 6, 173-181. [CrossRef]

29. Shankar, S.S.; Rai, A.; Ahmad, A.; Sastry, M. Rapid synthesis of Au, Ag, and bimetallic Au core-Ag shell nanoparticles using Neem (Azadirachta indica) leaf broth. J. Colloid Interface Sci. 2004, 275, 496-502. [CrossRef] [PubMed]

30. Jain, S.; Mehata, M.S. Medicinal Plant Leaf Extract and Pure Flavonoid Mediated Green Synthesis of Silver Nanoparticles and their Enhanced Antibacterial Property. Sci. Rep. 2017, 7, 15867. [CrossRef] [PubMed]

31. Singhal, G.; Bhavesh, R.; Kasariya, K.; Sharma, A.R.; Singh, R.P. Biosynthesis of silver nanoparticles using Ocimum sanctum (Tulsi) leaf extract and screening its antimicrobial activity. J. Nanopart. Res. 2011, 13, 2981-2988. [CrossRef]

32. Verma, A.; Mehata, M.S. Controllable synthesis of silver nanoparticles using Neem leaves and their antimicrobial activity. J. Radiat. Res. Appl. Sci. 2016, 9, 109-115. [CrossRef]

33. Prathna, T.C.; Chandrasekaran, N.; Raichur, A.M.; Mukherjee, A. Biomimetic synthesis of silver nanoparticles by Citrus limon (lemon) aqueous extract and theoretical prediction of particle size. Colloids Surf. B Biointerfaces 2011, 82, 152-159. [CrossRef] [PubMed]

34. Miethling-Graff, R.; Rumpker, R.; Richter, M.; Verano-Braga, T.; Kjeldsen, F.; Brewer, J.; Hoyland, J.; Rubahn, H.-G.; Erdmann, H. Exposure to silver nanoparticles induces size- and dose-dependent oxidative stress and cytotoxicity in human colon carcinoma cells. Toxicol. In Vitro 2014, 28, 1280-1289. [CrossRef] [PubMed]

35. Durai, P.; Chinnasamy, A.; Gajendran, B.; Ramar, M.; Pappu, S.; Kasivelu, G.; Thirunavukkarasu, A. Synthesis and characterization of silver nanoparticles using crystal compound of sodium para-hydroxybenzoate tetrahydrate isolated from Vitex negundo L. leaves and its apoptotic effect on human colon cancer cell lines. Eur. J. Med. Chem. 2014, 84, 90-99. [CrossRef] [PubMed]

36. Satapathy, S.R.; Mohapatra, P.; Preet, R.; Das, D.; Sarkar, B.; Choudhuri, T.; Wyatt, M.D.; Kundu, C.N. Silver-based nanoparticles induce apoptosis in human colon cancer cells mediated through p53. Nanomedicine 2013, 8, 1307-1322. [CrossRef] [PubMed] 
37. Mata, R.; Nakkala, J.R.; Sadras, S.R. Biogenic silver nanoparticles from Abutilon indicum: Their antioxidant, antibacterial and cytotoxic effects in vitro. Colloids Surf. B Biointerfaces 2015, 128, 276-286. [CrossRef] [PubMed]

38. Azizi, M.; Ghourchian, H.; Yazdian, F.; Bagherifam, S.; Bekhradnia, S.; Nyström, B. Anti-cancerous effect of albumin coated silver nanoparticles on MDA-MB 231 human breast cancer cell line. Sci. Rep. 2017, 7, 5178. [CrossRef] [PubMed]

39. Yuan, Y.-G.; Wang, Y.-H.; Xing, H.-H.; Gurunathan, S. Quercetin-mediated synthesis of graphene oxide-silver nanoparticle nanocomposites: A suitable alternative nanotherapy for neuroblastoma. Int. J. Nanomed. 2017, 12, 5819-5839. [CrossRef] [PubMed]

40. Burd, J.F.; Usategui-Gomez, M. A colorimetric assay for serum lactate dehydrogenase. Clin. Chim. Acta 1973, 46, 223-227. [CrossRef]

41. Chan, F.K.-M.; Moriwaki, K.; De Rosa, M.J. Detection of necrosis by release of lactate dehydrogenase activity. Methods Mol. Biol. 2013, 979, 65-70. [CrossRef] [PubMed]

42. Castiglioni, S.; Caspani, C.; Cazzaniga, A.; Maier, J.A. Short- and long-term effects of silver nanoparticles on human microvascular endothelial cells. World J. Biol. Chem. 2014, 5, 457-464. [CrossRef] [PubMed]

43. Brayner, R. The toxicological impact of nanoparticles. Nano Today 2008, 3, 48-55. [CrossRef]

44. Yuan, Y.-G.; Peng, Q.-L.; Gurunathan, S. Silver nanoparticles enhance the apoptotic potential of gemcitabine in human ovarian cancer cells: Combination therapy for effective cancer treatment. Int. J. Nanomed. 2017, 12, 6487-6502. [CrossRef] [PubMed]

45. Han, J.W.; Gurunathan, S.; Choi, Y.-J.; Kim, J.-H. Dual functions of silver nanoparticles in F9 teratocarcinoma stem cells, a suitable model for evaluating cytotoxicity- and differentiation-mediated cancer therapy. Int. J. Nanomed. 2017, 12, 7529-7549. [CrossRef] [PubMed]

46. Han, J.W.; Jeong, J.-K.; Gurunathan, S.; Choi, Y.-J.; Das, J.; Kwon, D.-N.; Cho, S.-G.; Park, C.; Seo, H.G.; Park, J.-K.; et al. Male- and female-derived somatic and germ cell-specific toxicity of silver nanoparticles in mouse. Nanotoxicology 2016, 10, 361-373. [CrossRef] [PubMed]

47. Buttacavoli, M.; Albanese, N.N.; di Cara, G.; Alduina, R.; Faleri, C.; Gallo, M.; Pizzolanti, G.; Gallo, G.; Feo, S.; Baldi, F.; Cancemi, P. Anticancer activity of biogenerated silver nanoparticles: An integrated proteomic investigation. Oncotarget 2018, 9, 9685-9705. [CrossRef] [PubMed]

48. Travan, A.; Pelillo, C.; Donati, I.; Marsich, E.; Benincasa, M.; Scarpa, T.; Semeraro, S.; Turco, G.; Gennaro, R.; Paoletti, S. Non-cytotoxic Silver Nanoparticle-Polysaccharide Nanocomposites with Antimicrobial Activity. Biomacromolecules 2009, 10, 1429-1435. [CrossRef] [PubMed]

49. Pelicano, H.; Carney, D.; Huang, P. ROS stress in cancer cells and therapeutic implications. Drug Resist. Updat. 2004, 7, 97-110. [CrossRef] [PubMed]

50. Gliga, A.R.; di Bucchianico, S.; Lindvall, J.; Fadeel, B.; Karlsson, H.L. RNA-sequencing reveals long-term effects of silver nanoparticles on human lung cells. Sci. Rep. 2018, 8, 6668. [CrossRef] [PubMed]

51. AshaRani, P.V.; Low Kah Mun, G.; Hande, M.P.; Valiyaveettil, S. Cytotoxicity and Genotoxicity of Silver Nanoparticles in Human Cells. ACS Nano 2009, 3, 279-290. [CrossRef] [PubMed]

52. Choi, Y.-J.; Park, J.-H.; Han, J.W.; Kim, E.; Jae-Wook, O.; Lee, S.Y.; Kim, J.-H.; Gurunathan, S. Differential Cytotoxic Potential of Silver Nanoparticles in Human Ovarian Cancer Cells and Ovarian Cancer Stem Cells. Int. J. Mol. Sci. 2016, 17, 2077. [CrossRef] [PubMed]

53. Zhang, X.-F.; Shen, W.; Gurunathan, S. Silver Nanoparticle-Mediated Cellular Responses in Various Cell Lines: An in Vitro Model. Int. J. Mol. Sci. 2016, 17, 1603. [CrossRef] [PubMed]

54. Orlowski, P.; Krzyzowska, M.; Zdanowski, R.; Winnicka, A.; Nowakowska, J.; Stankiewicz, W.; Tomaszewska, E.; Celichowski, G.; Grobelny, J. Assessment of in vitro cellular responses of monocytes and keratinocytes to tannic acid modified silver nanoparticles. Toxicol. In Vitro. 2013, 27, 1798-1808. [CrossRef] [PubMed]

55. Maurer, L.L.; Meyer, J.N. A systematic review of evidence for silver nanoparticle-induced mitochondrial toxicity. Environ. Sci. Nano 2016, 3, 311-322. [CrossRef]

56. Neustadt, J.; Pieczenik, S.R. Medication-induced mitochondrial damage and disease. Mol. Nutr. Food Res. 2008, 52, 780-788. [CrossRef] [PubMed]

57. Navarro, E.; Piccapietra, F.; Wagner, B.; Marconi, F.; Kaegi, R.; Odzak, N.; Sigg, L.; Behra, R. Toxicity of silver nanoparticles to Chlamydomonas reinhardtii. Environ. Sci. Technol. 2008, 42, 8959-8964. [CrossRef] [PubMed] 
58. Schieber, M.; Chandel, N.S. ROS function in redox signaling and oxidative stress. Curr. Biol. 2014, 24, R453-R462. [CrossRef] [PubMed]

59. Elmore, S. Apoptosis: A Review of Programmed Cell Death. Toxicol. Pathol. 2007, 35, 495-516. [CrossRef] [PubMed]

60. Liu, F.; Mahmood, M.; Xu, Y.; Watanabe, F.; Biris, A.S.; Hansen, D.K.; Inselman, A.; Casciano, D.; Patterson, T.A.; Paule, M.G.; et al. Effects of silver nanoparticles on human and rat embryonic neural stem cells. Front. Neurosci. 2015, 9, 115. [CrossRef] [PubMed]

61. Assık, E.; Aslan, T.N.; Volkan, M.; Güray, N.T. 2-Amino-2-deoxy-glucose conjugated cobalt ferrite magnetic nanoparticle (2DG-MNP) as a targeting agent for breast cancer cells. Environ. Toxicol. Pharmacol. 2016, 41, 272-278. [CrossRef] [PubMed]

62. Hsu, Y.-C.; Chen, M.-J.; Huang, T.-Y. Inducement of mitosis delay by cucurbitacin E, a novel tetracyclic triterpene from climbing stem of Cucumis melo L., through GADD45 $\gamma$ in human brain malignant glioma (GBM) 8401 cells. Cell Death Dis. 2014, 5, e1087. [CrossRef] [PubMed]

63. Hsu, Y.-C.; Huang, T.-Y.; Chen, M.-J. Therapeutic ROS targeting of GADD45 $\gamma$ in the induction of G2/M arrest in primary human colorectal cancer cell lines by cucurbitacin E. Cell Death Dis. 2014, 5, e1198. [CrossRef] [PubMed]

(C) 2018 by the authors. Licensee MDPI, Basel, Switzerland. This article is an open access article distributed under the terms and conditions of the Creative Commons Attribution (CC BY) license (http:/ / creativecommons.org/licenses/by/4.0/). 